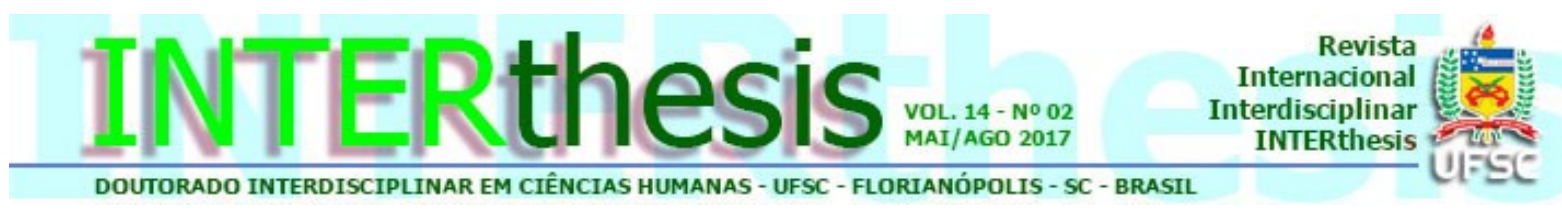

\title{
CONCEPÇÕES EM REDUÇÃO DE DANOS NO PROJETO CONSULTÓRIO DE RUA: PRÁTICAS NA SAÚDE MENTAL
}

\section{Resumo:}

Maria Eniana Araújo Gomes Pacheco ${ }^{1}$ João Tadeu de Andrade ${ }^{2}$

Discutem-se as concepções da Redução de Danos no âmbito do uso e abuso das substâncias psicoativas através das práticas terapêuticas da abordagem de rua em território urbano, no Projeto Consultório de Rua. Trata-se de um estudo empírico, com natureza qualitativa e exploratória, no município de Fortaleza-CE. A sistematização do conhecimento desdobrou-se na perspectiva crítico-analítica de análise do fenômeno social e de suas relações com o campo da saúde mental, pela práxis social, através de pesquisa de campo, por meio do diário de campo e entrevista semiestruturada, e revisão de literatura especializada. Por meio da análise de conteúdo consideraram-se as categorias Cuidado, Acessibilidade, Territorialidade, Estratégia, Política e Escuta. Foi discutida a Política de Redução de Danos enquanto estratégia transversal nas práticas terapêuticas da abordagem de rua na saúde pública.

Palavras-chave: Redução de Danos. Dependência Química. Consultório de Rua. Saúde Pública.

\section{INTRODUÇÃO}

Atualmente no Brasil, o Ministério da Saúde, reconhece o abuso de substâncias psicoativas como um grave problema de saúde pública e recomenda ações terapêuticas voltadas à integração, prevenção, reabilitação, educação e promoção da saúde no campo das práticas. Dentre as ações terapêuticas em espaços institucionalizados da saúde, a proposta da Redução de Danos (RD) inserese nas políticas centrais do Sistema Único de Saúde (SUS), por meio da Política Nacional da Atenção Básica, Política Nacional de Saúde Mental, Política do Ministério da Saúde de Atenção Integral de Usuários de Álcool e outras Drogas e da Política Nacional sobre Drogas (BRASIL, 2006).

\footnotetext{
1 Doutoranda em Psicologia pela Universidade de Fortaleza, Ceará, CE, Brasil. Mestre em Políticas Públicas e Sociedade pela Universidade Estadual do Ceará. Bolsista da Fundação Cearense de Apoio ao Desenvolvimento Científico e Tecnológico. E-mail: enianaagp@yahoo.com.br

2 Doutor em Antropologia pela Universidade Federal da Bahia, Salvador, BA, Brasil. Pós-doutorado na University of Toronto, Canada. Professor adjunto da Universidade Estadual do Ceará, Fortaleza, CE, Brasil E-mail: joao.andrade@uece.br
} 
Em 1994, o SUS, inseriu oficialmente no Brasil a RD enquanto política estratégica no âmbito da saúde pública que visa controlar possíveis consequências negativas associadas ao consumo de substâncias psicoativas (termo farmacológico utilizado atualmente para se referir às substâncias que modificam o funcionamento do Sistema Nervoso Central) lícitas e ilícitas sem, necessariamente, interferir na oferta ou consumo, respeitando a liberdade de escolha, buscando inclusão social e cidadania para os usuários, em seus contextos de vida (BRASIL, 2004).

Neste cenário, em 2009, foi apresentado pelo Ministério da Saúde, o Projeto Consultório de Rua (PCR), destinado ao atendimento da população em situação de rua. Esse projeto foi indicado como uma das estratégias para o Plano Emergencial de Ampliação de Acesso ao Tratamento e Prevenção em Álcool e outras Drogas (PEAD). No ano seguinte esse serviço foi também incluído no Plano Integrado de Enfrentamento ao Crack e outras Drogas (PIEC) (BRASIL, 2010).

O PCR desenvolve ações preventivas na perspectiva da Redução de Danos e funciona como um dispositivo para além do modelo biomédico, que se distancia da lógica de demanda espontânea e abordagem única voltada à abstinência, caracterizando-se fundamentalmente por oferecer cuidados no próprio espaço da rua, respeitando o contexto sociocultural da população (BRASIL, 2010; OLIVEIRA, 2009).

Reconhecendo a presença das ações terapêuticas existentes no âmbito da saúde pública, o presente artigo objetiva discutir as concepções da Redução de Danos para o profissional, integrante da equipe do PCR, que atua junto a usuários de substâncias psicoativas, em situação de rua. Reverberam-se os sentidos aplicados sob um conjunto de práticas de cuidado e de atenção aos usuários de substâncias psicoativas.

\section{METODOLOGIA}

Optou-se pela realização de um estudo qualitativo analítico tendo em vista a subjetividade que circunda os trabalhos com grupos sociais e o sujeito biopsicossocial (MARTINELLI, 1999).

Essa pesquisa foi submetida à análise do Comitê de Ética e Pesquisa da Universidade Estadual do Ceará e após aprovação os sujeitos convidados a 
participar do estudo tiveram acesso ao Termo de Consentimento Livre e Esclarecido, o qual foi assinado ao ser manifestado o desejo de contribuírem com a pesquisa.

Neste estudo foi considerada a entrevista semiestruturada audiogravada para coleta de dados, sendo utilizado um roteiro que abordou questões relacionadas às características dos participantes e aspectos relacionados ao objeto em apreensão.

Participaram cinco sujeitos da equipe do PCR e os critérios para a sua inclusão foram: 1) estar no serviço há pelo menos seis meses; 2) disponibilidade de tempo para a entrevista; e, por fim, 3) aceitar participar da pesquisa.

Esse grupo de sujeitos da pesquisa foi constituído por um Psicólogo, um Redutor de Danos, um Motorista, um Técnico de enfermagem e um Educador social. Como característica desse grupo tem-se que todos os sujeitos têm idade variando entre 27 e 53 anos e, dos cinco sujeitos, um tem formação de nível superior, dois, em redução de danos, um concluiu o curso técnico e dois não têm experiência anterior com saúde mental. Acrescenta-se a esse grupo o Supervisor da equipe do PCR que teve alguns de seus relatos registrados no diário de campo, durante observação sistemática, por considerarmos relevante para o estudo. Esses sujeitos, no período da pesquisa, possuíam vínculo empregatício de terceirização com o Instituto de Desenvolvimento Tecnológico e Apoio a Gestão em Saúde (IDGS).

Como cenário da pesquisa constou o município de Fortaleza no Estado do Ceará, região Nordeste do Brasil. Destaca-se que em 2011, período da pesquisa de campo, só existia essa equipe de CR em todo estado do Ceará. A equipe foi implementada após avaliação do Ministério da Saúde pela II Chamada Pública intitulada "Seleção de Projetos de Consultório de Rua e Redução de Danos", em dezembro de 2009 (BRASIL, 2010).

No município de Fortaleza, local de recorte deste estudo, o Programa de Redução de Danos teve início no âmbito da Rede de Saúde Mental, Álcool e outras Drogas, sob a coordenação de colegiado ${ }^{3}$ desde 2005 , que, ao participar da seleção dos Projetos de Consultório de Rua, promovida pelo Ministério da Saúde, em 2009, obteve êxito.

\footnotetext{
${ }^{3}$ O Colegiado de Gestão em Saúde constitui-se por ser um espaço de negociação, pactuação e cogestão solidária. Em Fortaleza, o Colegiado de Saúde Mental, no período da pesquisa, constituía-se por um Psiquiatra e duas Psicólogas que buscavam garantir e aprimorar a aplicação dos princípios do SUS.
}

R. Inter. Interdisc. INTERthesis, Florianópolis, v.14, n.2, p.57-74 Mai.-Ago. 2017 
A técnica adotada para o processamento do material empírico foi a análise de conteúdo proposta por Bardin (1979) em que se considera na modalidade temática as categorias Cuidado, Acessibilidade, Territorialidade, Estratégia, Política e Escuta.

O relatório produzido constituiu conteúdo de Dissertação de Mestrado defendida no âmbito do Mestrado Acadêmico em Políticas Públicas e Sociedade da UECE em 2012, do qual este artigo é resultado.

\section{O TEXTO E O CONTEXTO DA REDUÇÃO DE DANOS}

Acerca da questão do uso abusivo de substâncias psicoativas no espaço urbano, em Espinheira (2004) e MacRae (2001) há o reconhecimento das diversidades nos modos de usos. Essas diversidades no âmbito da saúde são compreendidas mediante as singularidades do sujeito pelo respeito às liberdades de escolhas, propondo alternativas que reduzam os danos durante os diferentes modos de uso (BRASIL, 2012).

Enquanto um dispositivo da saúde, o PCR atende crianças, adolescentes, adultos e idosos em condições de vulnerabilidade social, e em situação de rua. Composto por uma equipe multidisciplinar que adota a Redução de Danos como uma das estratégias de intervenção, o PCR se ancora na interdisciplinaridade da equipe multiprofissional visando a integralidade da assistência. As ações voltam-se aos direitos humanos e inclusão social, desmistificando estigmas por meio das ações em redução de danos e intersetorialidade (BRASIL, 2012).

Para o Ministério da Saúde os Consultórios de Rua, configuram-se enquanto:

“[...] dispositivos clínico-comunitários que ofertam cuidados em saúde aos usuários em seus próprios contextos de vida, adaptados para as especificidades de uma população complexa. Promovem a acessibilidade a serviços da rede institucionalizada, a assistência integral e a promoção de laços sociais para os usuários em situação de exclusão social, possibilitando um espaço concreto do exercício de direitos e cidadania. Sua estrutura de funcionamento conta com uma equipe volante mínima com formação multidisciplinar constituída por profissionais da saúde mental, da atenção básica, de pelo menos um profissional da assistência social, sendo estes: médico, assistente social, psicólogo, outros profissionais de nível superior, redutores de danos, técnicos de enfermagem e educadores sociais. Além desses, eventualmente, poderá contar com oficineiros que possam, estrategicamente, desenvolver atividades de arte-expressão" (BRASIL, 2010, p. 10). 
Sob essa configuração do cuidado e acessibilidade, encontram-se os nossos sujeitos de estudo.

Na categoria Cuidado contempla-se a evolução do conceito de integralidade que na perspectiva da RD é moldada pela articulação ativa entre profissionais e pacientes em rede, procurando minimizar os possíveis danos que o consumo de uma substância psicoativa pode causar à saúde na dimensão biopsicossocial da pessoa (PACHECO, 2013).

Visa-se à promoção da saúde, cidadania e direitos humanos, levando em consideração a necessidade real do indivíduo e não o direcionando à lógica da abstinência ou da internação. Deste modo as intervenções em RD assumem um modo de cuidado que acolhe o sujeito em seu sofrimento frente às fragilidades sociais circundantes (PACHECO, 2013).

Nos depoimentos a seguir visualizam-se práticas em saúde que concebem o indivíduo numa perspectiva ampla de cuidado, sem distanciá-lo de sua realidade social, podendo ser observado no relato do Colaborador 1 ao afirmar que "cuidar da saúde, cuidar de todas as formas como: saúde, sabedoria, inteligência e dignidade", assim como também no relato do Supervisor segundo o qual "não vamos esquecernos do cuidado em si inicialmente... vamos criar as alternativas possíveis".

Nas falas dos profissionais estudados aparece o cuidado não somente na perspectiva biológica e unitária, mas na relacional. Observa-se o desenvolvimento do cuidar em saúde a partir do processo de interação, encontro, consideração, reconstrução e desejo por construir projetos. Os participantes enfatizaram o cuidado integral que incorpora a ideia da assistência à saúde, unificando ações preventivas, curativas e de reabilitação. Ressalta-se que o cuidado terapêutico na atenção psicossocial da saúde, busca conhecer as dimensões biológica, psicológica e social dos sujeitos (PACHECO, 2013).

Na categoria Redução de Danos como Acessibilidade discute-se a expressão desta na perspectiva das oportunidades aos serviços de saúde como um direito que é mediado por uma abordagem estratégica e diferenciada de acesso do usuário de drogas, em situação de vulnerabilidade social, como pode ser verificado pelas próprias palavras de um dos entrevistados logo a seguir.

A redução de danos é uma estratégia, uma tecnologia que seja de uma funcionalidade muito grande e vista como uma possibilidade de acesso do usuário aos seus direitos. Então, o usuário que quer continuar fazendo uso de qualquer tipo de substância, continua tendo os seus direitos para fazer

R. Inter. Interdisc. INTERthesis, Florianópolis, v.14, n.2, p.57-74 Mai.-Ago. 2017 
algum tipo de tratamento, a pensar sobre sua saúde, a pensar sobre a forma de uso, mesmo que ele continue usando. Ele tem mais opções. (Colaborador 5).

Nessa perspectiva a RD mantém estreita relação com a clínica ampliada que enquanto diretriz da Política Nacional de Álcool e outras Drogas, do Ministério da Saúde, concebe os usuários de substância psicoativa como sujeitos corresponsáveis pela produção de saúde ao se posicionarem de modo ativo na relação clínica.

Outro ângulo a ser explorado na perspectiva da clínica ampliada, dentro da problematização da relação dialógica terapêutica de promoção da acessibilidade, são as ações de território. Nas ações terapêuticas de território a escuta ativa do profissional volta-se para o sujeito em atendimento, considerando sua singularidade. Nesse contexto, o saber do especialista não será o único a ser relevante, pois no processo da produção de saúde consideram-se os sujeitos singulares na sua autonomia (CAMPOS, 1998; PACHECO, 2013).

É interessante perceber que na RD a clínica ampliada se molda por intermédio do procedimento clínico-político ao criar novos dispositivos na atenção e assistência a usuários de substâncias psicoativas. Esses novos dispositivos podem ser percebidos por intermédio de supervisões, assembléias, incentivos ao conhecimento dos direitos humanos e direitos constitucionais, criação dos cachimbos de madeiras para prevenção de Hepatite $C$ entre usuários de crack, substituição de crack por maconha, dentre outras ações (CAMPOS, 2000).

Por intermédio desses novos dispositivos a transversalização e a operacionalização da RD passam a exigir diferentes respostas e encaminhamentos das diferentes disciplinas e serviços ao integrar questões como AIDS e drogas nas ações de atenção à saúde (CAMPOS, 2000). Nessa perspectiva, tem-se nas diretrizes da Política Nacional de Álcool e outras Drogas a RD como mais uma possibilidade de intervenção da prática em saúde por meio da ação terapêutica de território.

Seguindo esse pensamento, o foco da Redução de Danos no PCR não é o objeto uso nocivo, abuso ou dependência da substância psicoativa, mas a melhoria na qualidade de vida do indivíduo pela promoção da saúde. Essa reflexão também se fundamenta em Moreira, Silveira e Andreoli (2006), quando afirmam que a RD tem suas propostas transversalizadoras pela promoção da saúde quando ofertam 
ações inclusivas por intermédio das parcerias intersetoriais, investindo, assim, na autonomia dos indivíduos, concebendo-os independentemente do uso.

Acrescenta-se que dentre as ações de atenção à saúde na $R D, 0$ desenvolvimento da ação terapêutica territorial e a promoção da acessibilidade ao SUS, ancoram-se na Política de Atenção Básica, em que a abstinência ${ }^{4}$ não é o único objetivo a ser alcançado quando se lida com as singularidades dos sujeitos (BRASIL, 2004).

Nas singularidades temos aqueles sujeitos que querem parar de usar a substância psicoativa, porém não conseguem ficar sem seu uso e os que optam por continuar a usar de um modo que não venha a prejudicar suas rotinas diárias como trabalho, atividades de lazer, estabilidade na relação com família e amigos, alimentação e sono regular (PACHECO, 2013).

Com base nas singularidades do uso problemático das substâncias psicoativas, a categoria Redução de Danos enquanto Territorialidade apresenta como princípio metodológico de conhecimento que primeiro se deve conhecer o território para, só após, se intervir. Essa indicação advém das imprevisibilidades, tanto clínicas quanto políticas, no contexto dos usuários de substâncias psicoativas (PACHECO, 2013).

Compreendendo o espaço no seu âmbito político, econômico e cultural, Santos (2003) concebe, em seus estudos sobre território, que o espaço urbano se assume enquanto possuidor de característica dinâmica cercado por conflitos inerentes à própria condição humana do relacionar-se socialmente.

Por isso, na perspectiva da territorialidade, segundo o autor supracitado, temse um território, fragmentado e fragmentador, integrado e integrador, que externa as relações políticas e econômicas do espaço local a polos de decisões globais.

Haesbaert (2004) observa o aparecimento e desaparecimento dos territórios devido a sua característica de mobilidade e transitoriedade. Complementando essa reflexão, Pereira (2000) considera o território na perspectiva da territorialidade enquanto um lugar de construção e "produto da apropriação, da valorização simbólica de um grupo em relação ao espaço vivido" (p. 52)

Já na territorialização da saúde tem-se a técnica de reordenação do trabalho de acordo com o vínculo terapêutico entre equipe e usuários, destacando-se sua

${ }^{4} \mathrm{~A}$ abstinência é a ausência da substância psicoativa no organismo.

R. Inter. Interdisc. INTERthesis, Florianópolis, v.14, n.2, p.57-74 Mai.-Ago. 2017 
importância no cenário atual da organização da rede e dos serviços de saúde, bem como das práticas sanitárias locais. Os objetivos da territorialização em saúde são: 1-Delimitar um território de abrangência; 2- Definir a população favorecida e apropriar-se juntamente com ela do perfil da área e da comunidade; 3- Reconhecer dentro da área de abrangência barreiras e acessibilidade; 4- Conhecer condições de infraestrutura e recursos sociais; 5- Levantar problemas e necessidades, definindo um diagnóstico contínuo da comunidade; 6- Identificar o perfil demográfico, epidemiológico, socioeconômico e ambiental; 7- Identificar e assessorar-se em lideranças formais e informais; 8- Potencializar os resultados e os recursos presentes nesse território. Como produto desse processo pode se obter 0 estabelecimento de uma rede social solidária, que resultará em melhoria da condição de saúde da comunidade e dos trabalhadores inseridos nesse espaço e na ampliação de projetos sociais envolvendo diferentes sujeitos da comunidade na busca de recursos (FERREIRA, 2009).

Merece destaque na prática dialógica da proposta terapêutica de rua da RD, que a relação cuidador-paciente siga o princípio metodológico da produção de conhecimento segundo o qual primeiro se deve conhecer para posteriormente intervir. Essa diretriz considera as imprevisibilidades, tanto clínicas quanto políticas, no contexto dos usuários de substâncias psicoativas de modo que, nas abordagens terapêuticas, se parte do seu saber (PACHECO, 2013).

\begin{abstract}
Redução de danos, na rua, precisa compreender o espaço, que recursos tem, pensando que tipo de linha de redução de danos você vai usar. Então, o espaço vai ser muito determinante para como a gente vai propor as mudanças. Porque, no caso, tem alguns locais que você faz propostas e é feito as negociações em redução de danos. Você negocia com o que você tem para negociar. Tem locais que tem como negociar alguns fatores, enquanto outros não tem como negociar aqueles mesmos fatores. $E$ isso vai mudando como agente vai trabalhar na redução de danos. (Colaborador 5).
\end{abstract}

Ademais, na RD se concebe o sujeito em sua dimensão sócio-histórica, pertencente a um lócus, na medida em que o mesmo interage com seu entorno, fazendo-se sujeito (SARACENO, 2001; TURCK, 2002).

Nesse lócus a categoria Redução de Danos como Estratégia é moldada pelas práticas terapêuticas em saúde resultante das abordagens de rua.

Discute-se no depoimento a seguir, terapêuticas que remetem a diferentes estratégias em saúde, desprovidas de preconceito, aos usuários em situação de uso problemático das substâncias psicoativas, pelas calçadas e guetos da cidade. São 
práticas terapêuticas estratégicas em redução de danos estimadas a partir dos saberes advindos da população usuária de substância psicoativa atendida: não condicionamento da prática em saúde à abstinência total e imediata; estímulo às práticas de autocuidado; construção de projeto terapêutico compartilhado; estabelecimento de objetivos a serem alcançados na busca por cidadania; aconselhamento para a diminuição da quantidade ou frequência do consumo de droga; substituição das substâncias mais danosas por outras que causem menores prejuízos à saúde; e fortalecimento de vínculos afetivos.

[...] uma estratégia de como a gente chega na rua. Todos os saberes vão ser importantes para nós irmos trabalhando como chegar na rua. Hoje o conhecimento da redução de danos vem para mim muito mais das experiências do que vejo na rua, das coisas que leio e de experiências práticas também. (Colaborador 5)

Logo, a concepção da Redução de Danos tem seu conceito ampliado ao desenvolver práticas terapêuticas em saúde pública ofertada às diferentes extensões da vida social dos indivíduos de modo operacional e aberta que visam prevenir ou reduzir as consequências negativas associadas ao uso de drogas com ações de prevenção na saúde, sem necessariamente interferir na oferta ou consumo, sendo orienta pelo respeito à liberdade de escolha (PACHECO, 2013).

De tal modo, dentre as estratégias e intervenções interdisciplinares e multiprofissionais no PCR, as práticas em saúde, embasadas pela Redução de Danos, se voltam para a promoção, prevenção e tratamento por intermédio dos cuidados primários no espaço da rua (BRASIL, 2010a).

Como alternativa que diminui os danos à saúde, a $\mathrm{RD}$ enquanto estratégia de trabalho na atualidade promove a aproximação e o acesso dos profissionais da equipe do PCR à população usuária de droga em situação de rua. É uma alternativa de saúde pública que reconhece a abstinência como um resultado, sem desconsiderar alternativas outras da atenção em saúde (MARLATT, 1999).

Estas estratégias em RD pretendem reduzir os prejuízos de natureza biológica, social, cultural e econômica aos usuários de substâncias psicoativas, promovendo-Ihes o acesso aos serviços de saúde como uma alternativa, adotando a relação profissional-usuário como um caminho para a construção de vínculos (MARLATT, 1999).

Seguindo esse pensamento, o foco da Redução de Danos no PCR não é o objeto uso nocivo, abuso ou dependência da substância psicoativa, mas a melhoria na qualidade de vida do indivíduo pela promoção da saúde. Essa reflexão também R. Inter. Interdisc. INTERthesis, Florianópolis, v.14, n.2, p.57-74 Mai.-Ago. 2017 
fundamenta-se em Moreira, Silveira e Andreoli (2006), quando afirmam que a RD tem suas propostas transversalizadoras pela promoção da saúde quando ofertam ações inclusivas por intermédio das parcerias intersetoriais, investindo, assim, na autonomia dos indivíduos, concebendo-os independentemente do uso.

Situada em meio a um trajeto histórico a Redução de Danos transpôs as ações únicas direcionadas à prevenção de DST/AIDS para construir estratégias que investem na promoção da saúde. Dentre essas estratégias a Redução de Danos é indicada pelo Ministério da Saúde como uma:

"[...] estratégia de saúde pública que visa reduzir os danos causados pelo abuso de drogas lícitas e ilícitas, resgatando o usuário em seu papel autoregulador, sem a preconização imediata da abstinência e incentivando-o à mobilização social - nas ações de prevenção e de tratamento, como um método clínico-político de ação territorial inserido na perspectiva da clínica ampliada" (BRASIL, 2004, p. 25).

Acrescenta-se que princípios como dignidade da pessoa humana e direitos humanos aos usuários de drogas e membros de outros grupos, também estigmatizados e oprimidos, são considerados nas diferentes estratégias da prática em Redução de Danos. Nessa perspectiva, a RD pode ser compreendida como um paradigma às intervenções clínicas de diferentes áreas (MARLATT,1999).

Dessa maneira, a RD procura minimizar os possíveis danos que o consumo de uma substância psicoativa pode causar à saúde na dimensão biopsicossocial da pessoa, visando à promoção da saúde, cidadania e direitos humanos, levando em consideração a necessidade real do indivíduo e não o direcionando à lógica da abstinência ou da internação. Deste modo as intervenções em redução de danos assumem um modo de cuidado que acolhe o sujeito em seu sofrimento frente às fragilidades sociais circundantes.

Na categoria Política há a compreensão da RD como um ato educativo que permite ao profissional do PCR estimular a conscientização dos usuários de substâncias psicoativas a fim de que assumam uma maior autonomia sobre os seus atos.

Trata-se de uma política operacional dialógica educativa entre profissional e usuário com vistas a reduzir os danos causados pelo uso problemático de substâncias psicoativas através do princípio da transversalidade na gestão comum. $\mathrm{Na}$ ocasião destaca-se a importância das discussões entre profissionais e usuários do serviço sobre as práticas em saúde que se voltam à problematização dos contextos reais de ganhos e perdas mediante o uso problemático, com destaque à R. Inter. Interdisc. INTERthesis, Florianópolis, v.14, n.2, p.57-74 Mai.-Ago. 2017 
co-responsabilização e autonomia presentes na relação dialógica para estabelecimento do plano terapêutico singular (MERHY, 2002, PACHECO, 2013).

Dessa maneira é possível se criar práticas em saúde com procedimento estratégico clínico-político em que o foco não é o usuário em processo de adoecimento, mas o sujeito em potencial para eleger prazeres e interesses alternativos, além do uso problemático de drogas. São práticas que reconhecem a capacidade de decidir e participar, demarcando sua especificidade de se voltar para os processos e sujeitos que produzem saúde (PACHECO, 2013).

É o fazer da dimensão política de educação voltada à conscientização e autonomia que problematiza os modos de produção da saúde em defesa da vida, quebrando os paradigmas da normalização rígida dos processos de organização e definição do acesso, com modos de cuidar ainda centrados na doença e queixa (PEDROSO, VIEIRA, 2009, PACHECO, 2013).

Daí a necessidade do compromisso institucional, individual e coletivo para um fazer desacomodado que cria alternativas, num esforço permanente de cogestão e corresponsabilidade, resultando na legitimação da integralidade no Sistema de Saúde para novos sentidos de abertura e invenção de modos singulares da existência humana (PEDROSO, VIEIRA, 2009).

$\mathrm{Na}$ fala seguinte evidencia-se a percepção do profissional do PCR em relação a necessidade da relação dialógica para o desenvolvimento de uma política conscientizadora sobre drogas, concebendo os usuários de substância psicoativa como sujeitos corresponsáveis pela produção de saúde ao se posicionarem de modo ativo na relação clínica. Nesse contexto, o saber do especialista não será o único a ser relevante, pois no processo da produção de políticas consideram-se os sujeitos singulares e coletivos na sua autonomia.

[...] percebo a Redução de Danos como uma política e uma série de práticas dialógicas e instrumentais que vem tentar reduzir os danos a saúde de quem está em uso abusivo de drogas. (Colaborador 3 ).

Resulta que o desafio da RD é o desenvolvimento da democracia que garanta às minorias a possibilidade de expressão e cooperação política, assim como a disponibilidade para as formas de sustentabilidade financeira a fim de exercerem funções públicas entendidas como gestão comum (MESQUITA, 1994; CAMPOS, 2000). 
Na categoria Redução de Danos como Escuta se foca na relação dialógica, no modo como os usuários de substâncias psicoativas são vistos e ouvidos.

A escuta presente no diálogo cotidiano das relações é mediada pelo olhar mútuo e o contexto das narrativas aproxima os sujeitos mesmo diante de suas ausências. Esse diálogo intercedido por conhecimentos sistematizados a partir de um arcabouço ético-político respaldam as práticas terapêuticas da saúde pública.

Trata-se de uma escuta que acolhe e aceita as diferentes formas de ser e estar no mundo, perante a diversidade. Constitui-se por uma postura ética com o outro diante da vivência relacional. Aos usuários de substâncias psicoativas é lhes garantido o direito de optarem por obter ou não tratamento. Desta maneira é possível tornar real uma relação entre usuário de substância psicoativa e profissional da saúde conforme depoimento a seguir:

A proposta mais viável que eu encontrei, até o momento, para estabelecer um diálogo com o usuário em uso de drogas. (colaborador 4).

Nos depoimentos dos sujeitos da amostra considera-se a escuta presente no desenvolvimento das reflexões sobre as formas de uso da substância psicoativa que possibilite melhor qualidade de vida à saúde. Compreende uma abordagem dialógica que se legitima pela humanização e é modelada por meio da relação entre profissionais e usuários de substâncias psicoativas, no desenvolvimento de práticas terapêuticas em saúde no SUS.

[...] vocês podem ouvir suas próprias histórias. Recontem sempre, revivam a identidade que ainda existe dos sujeitos quando em relação com vocês. Busquem a ancestralidade ao falar do presente, trazendo a figura dos antepassados para dentro dos sujeitos. A angústia move e ela nasce da necessidade de se escolher o que se quer ser no aqui-agora. Reconheçam o sujeito, no campo social do cuidado. (Supervisor)

A escuta presente no campo social do cuidado é transversal às relações dialógicas entre profissionais da saúde e usuário dos serviços ofertados, na medida em que coloca os diversos saberes e práticas no mesmo plano. Destaca-se ainda que mesmo havendo uma desestabilização das adjacências dos saberes implicados em territórios de poder, mediante práticas de trabalho em saúde, por meio das relações dialógicas, é possível ser produzido um plano de ação comum (PEDROSO, VIEIRA, 2009).

Não se trata de uma comunicação vertical ou horizontal, mas inter-relacional na produção do diálogo que distancia o modelo tradicional das práticas de saúde que separa quem elabora daquele que executa (PEDROSO, VIEIRA, 2009).

R. Inter. Interdisc. INTERthesis, Florianópolis, v.14, n.2, p.57-74 Mai.-Ago. 2017 


\section{CONSIDERAÇÕES FINAIS}

Este estudo buscou investigar a concepção da Redução de Danos (RD) para o profissional, membro da equipe do PCR que atua junto aos usuários de substâncias psicoativas em situação de rua.

A experiência de atuação nessa área e os resultados do estudo permitem apontar que para reduzir danos à saúde frente ao uso da substância psicoativa é necessário o conhecimento dos sujeitos em sua perspectiva singular e coletiva, reconhecendo a importância da autonomia e da corresponsabilização destes no processo de melhoria da qualidade de vida.

A concepção da RD esteve por muito tempo entrelaçada à prevenção de DST/AIDS. Contudo, atualmente a compreensão volta-se para as estratégias que invistam em ações promovedoras da saúde. Nesse contexto, a concepção da RD transpõe o conhecimento técnico das ações únicas em saúde direcionadas a resolutividade de doenças oriundas do uso de drogas injetáveis.

Ao conhecermos as concepções da RD a partir de um grupo específico de profissionais identificamos por meio da análise de conteúdo, certa reflexão dos participantes sobre essa temática durante atividades cotidianas da abordagem de rua. Essas reflexões permitem uma reavaliação dos saberes desenvolvidos a partir de práticas terapêuticas realizadas durante a abordagem de rua.

Os profissionais do PCR pesquisados revelaram a Redução de Danos como Cuidado, Política, Escuta, Estratégia, Acessibilidade e Territorialidade.

Ao ser destacada a Redução de Danos como Cuidado, os profissionais enfatizaram que para além da perspectiva biológica há de se considerar também o âmbito psicossocial em meio a abordagem de rua junto aos usuários de substâncias psicoativas.

A questão da RD como Política compreende uma relação dialógica mobilizadora dos processos educativos no campo em que se enfatiza a autonomia e corresponsabilização do usuário de substância psicoativa sobre suas próprias ações a partir de orientações prestadas por profissionais do PCR ao buscarem discutir junto a estes as práticas em saúde. 
$\mathrm{Na}$ troca de saberes entre especialistas e usuários de substâncias psicoativas resulta na produção de políticas direcionadas para construção de sujeitos singulares e coletivos na sociedade.

Em relação à $R D$ compreendida como Escuta, a narrativa do usuário é acolhida pelo profissional do PCR que ancorado por conhecimentos sistematizados respaldam suas devolutivas a partir de práticas cotidianas nas terapêuticas da saúde pública. Quanto à RD percebida como Estratégia observa-se o condicionamento dos preceitos técnicos e práticas cotidianas para a promoção da abordagem de rua.

Ademais outra concepção da RD como Acessibilidade é percebida pelos profissionais enquanto oportunidade de vinculação a serviços de saúde e comunitários.

Houve também a apreensão da RD como Territorialidade em que dependendo das organizações grupais nos territórios específicos, a abordagem terapêutica de rua tende a diferenciar-se conforme as necessidades dos sujeitos a partir do uso nocivo, abuso ou mesmo da dependência das substâncias psicoativas.

Este estudo indica como sugestão a mobilização da educação permanente entre os profissionais na saúde que focada também no compartilhar das situações cotidianas produtoras de novos saberes. Por fim, o estudo oportunizou aos profissionais um momento para a expressão de suas compreensões acerca do propósito da RD. 


\title{
CONCEPTIONS ON HARM REDUCTION IN "CONSULTÓRIO DE RUA" PROJECT: PRACTICES IN MENTAL HEALTH
}

\begin{abstract}
We discuss the concepts of harm reduction in the context of the use and abuse of psychoactive substances through street approach's therapeutic practices in the urban territory, called the "Consultório de Rua" project. It is an empirical study with qualitative and exploratory nature, in the city of Fortaleza-CE. Knowledge's systematization deployed in a critical-analytical perspective of social phenomenon analysis and its relationship with the field of mental health, by the social praxis, through structured interviews and literature review. Through content analysis the following categories were considered: Care, Accessibility, Territoriality, Strategy and Politics. Harm reduction policy was presented as a transversal strategy in therapeutic practices to street approach and public health.
\end{abstract}

Keywords: Harm Reduction. Substance Dependence. Office. Public Health.

\section{CONCEPCIONES SOBRE REDUCCIÓN DE DAÑOS EN EL PROYETO CONSULTORIO DE CALLE: PRÁCTICAS EN SALUD MENTAL}

\section{Resumen}

Se discuten las concepciones de Reducción de Daños en el contexto del uso y abuso de sustancias psicoactivas a través de prácticas terapéuticas de abordage en la calle en territorio urbano, en el Proyecto Consultorio de Calle. Es un estudio empírico de naturaleza cualitativa y exploratoria, en la ciudad de Fortaleza, estado de Ceará. La sistematización del conocimiento se desarrolló por la la perspectiva crítica analítica del análisis del fenómeno social y su relación con el campo de la salud mental, la praxis social, a través de entrevistas estructuradas y revisión de la literatura. A través del análisis de contenido, son consideradas las categorías de Cuidado, Accesibilidad, Territorialidad, Estrategia, Política y Escucha. Se debatió la Política de Reducción de Daños como estrategia transversal en las prácticas terapéuticas de abordage en la calle, en salud pública.

Palabras-clave: Reducción de Daños. Dependencia Química. Consultorio de Calle. Salud Pública. 


\section{REFERÊNCIAS}

BARDIN, L. Análise de conteúdo. Tradução de Luiz Antero Reto e Augusto Pinheiro. São Paulo: Edições 70; 1979.

BRASIL. Ministério da Saúde. Secretaria Executiva. Secretaria de Atenção à Saúde. Coordenação Nacional DST/AIDS. A política do Ministério da Saúde para a atenção integral a usuários de álcool e outras drogas. 2. ed. Brasília: Ministério da Saúde, 2004.

Lei $n^{0} 11.343$, de 23 de agosto de 2006. Institui o Sistema Nacional de Políticas Públicas sobre Drogas - SISNAD; prescreve medidas para prevenção do uso indevido, atenção e reinserção social de usuários e dependentes de drogas; estabelece normas para repressão à produção não autorizada e ao tráfico ilícito de drogas; define crimes e dá outras providências. Diário Oficial da República do Brasil. Poder Executivo. Brasília-DF, 24 ago. 2006.

. Ministério da Saúde. Secretaria de Atenção à Saúde. Departamento de Ações Programáticas Estratégicas. Coordenação Geral de Saúde Mental, Álcool e Outras Drogas. II Chamada para Seleção de Projetos de Consultórios de Rua e Redução de Danos (PCR-II). Brasília: Ministério da Saúde, 2010.

.Ministério da Saúde. Coordenação Nacional de Saúde Mental. Consultórios de Rua do SUS. Material de trabalho para a II Oficina Nacional de Consultórios de Rua do SUS. Brasília: Ministério da Saúde/EPJN-FIOCRUZ, 2010a.

. Ministério da Saúde. Portaria $n^{\circ} 122$, de 25 de janeiro de 2012. Define as diretrizes de organização e financiamento das Equipes de Consultório na Rua. Brasília: Presidência da República, 2012.

CAMPOS, G. W. O anti-Taylor: sobre a invenção de um método para co-governar instituições de saúde produzindo liberdade e compromisso. Cadernos de Saúde Pública, 1998, n.14, p. 863-870.

Hucitec, 2000.

Um Método Para Análise e Co-Gestão de Coletivos. São Paulo:

ESPINHEIRA, Gey. Os tempos e as substâncias psicoativas das drogas. In: ALBA, R. A. et al. Drogas: tempos, lugares e olhares sobre seu consumo. Salvador: EDUFBA, 2004,p. 11-26. 
FERREIRA, S. C. (Organizadores). Gestão em saúde: contribuições para análise da integralidade. Rio de Janeiro: EPSJV, 2009.

GALDURÓZ, J. C. F. Critérios diagnósticos: CID-10 e DSM-IV. In: Detecção do uso abusivo e diagnóstico da dependência de substâncias psicoativas. Módulo 3 / coordenação do módulo Telmo Mota Ronzani (UFJF). 4. ed. Brasília: Secretaria Nacional de Políticas sobre Drogas, 2011, p. 02-11.

HAESBAERT, R. O mito da desterritorialização: do 'fim dos territórios' à multiterritorialidade. 2. ed. Rio de Janeiro: Bertrand Brasil, 2004.

LE BRETON, D. Adeus ao corpo: antropologia e sociedade. São Paulo: Papirus, 2003.

MACRAE, E. Antropologia: aspectos sociais, culturais e ritualísticos. In: Dependência de drogas. Seibel, S. D. e Toscano Jr., A. São Paulo: Atheneu, 2001. p. 25-34.

MARLATT, G. A. Redução de danos: estratégias práticas para lidar com comportamentos de alto risco. Porto Alegre: Artmed, 1999.

MARTINELLI, M. L. Pesquisa qualitativa: um instigante desafio. São Paulo: Veras, 1999.

MELMAN, C. Alcoolismo, toxicomania, delinqüência. São Paulo: Escuta, 1992.

MERHY, E. E. Saúde: a cartografia do trabalho vivo. São Paulo: Hucitec, 2002.

MESQUITA, F.; BASTOS, F. I. Drogas e Aids, estratégias de redução de danos.São Paulo: Hucitec, 1994.

MOREIRA, F. G.; SILVEIRA, D. X. da; ANDREOLI, S. B. The drugs misuse related harm reduction in the health promoting schools. Ciência \& Saúde Coletiva, Rio de Janeiro, v. 11,n. 3, p. 807-816, 2006.

OLIEVENSTEIN, C. A droga: drogas e toxicômano. São Paulo: Brasiliense, 1980. 
OLIVEIRA. M. G. P. N. de. Consultório de rua: um relato de experiência. 2009. 146 f. Dissertação (Mestrado em Saúde Pública) - Universidade Federal da Bahia, Salvador, 2009.

PACHECO, M. E. A. G. Política de redução de danos a usuários de substâncias psicoativas: práticas terapêuticas no Projeto Consultório de Rua em Fortaleza, Ceará. 2013. 143f. Dissertação (Mestrado Acadêmico em Políticas Públicas e Sociedade) - Universidade Estadual do Ceará, Fortaleza, 2013.

PEDROSO, R., VIEIRA, M. Humanização das práticas de saúde: transversalizar em defesa da vida. In: Interface (Botucatu) vol.13 supl.1 Botucatu, 2009.

PEREIRA, P. A. P. Necessidades Humanas. São Paulo: Cortez, 2000.

SARACENO, B. Libertando identidades: da reabilitação psicossocial à cidadania possível. 2. ed. Rio de Janeiro, RJ: Te Corá/Instituto Franco Basaglia, 2001.

TURCK, M. da G. M. G. Rede interna e rede social: o desafio permanente na teia das relações sociais. Porto Alegre: Tomo Editorial, 2002.

Artigo:

Recebido em 23 de Maio de 2016.

Aceito em 05 de Dezembro de 2016. 